\title{
The role of NGOs in the process of ensuring compliance with MEAs
}

\author{
Astrid Epiney*
}

\begin{abstract}
Dieser Beitrag wurde erstmals wie folgt veröffentlicht:
Astrid Epiney, The Role of NGOs in the Process of Ensuring Compliance with MEAs, in: Beyerlin, Ulrich/Stoll, Peter-Tobias/Wolfrum, Rüdiger (Hrsg.), Ensuring Compliane with Multilateral Environmental Agreements: Academic Analysis and Views from Practice, Leiden/Boston 2006, S. 319-352. Es ist möglich, dass die Druckversion - die allein zitierfähig ist - im Verhältnis zu diesem Manuskript geringfügige Modifikationen enthält.
\end{abstract}

\section{Introduction}

The role of NGOs in the development and enforcement of international law has been constantly growing during the last decades, not only in international environmental law, but also in other fields of international law ${ }^{1}$. One can speculate about the reasons for this development; the most important ones seem to be the variation of actors in international law and the "democratisation" of international procedures which have contributed to the involvement of the "civil society", "represented" by NGOs, in the range of international actors. Furthermore, the increasing participation of NGOs in international decision-taking processes can be considered as one aspect among many others of globalisation ${ }^{2}$, which reflects fundamental changes in the concept of public international law. However, even if the role of NGOs has grown in various fields of international law, it is also clear that they are

I would like to thank Dr. Martin Scheyli for reading the paper and for his precious inputs and cand. iur. Mariana Joensson for having reviewed the language of the text.

As to the role of NGOs in international law in general cf., e.g., S. Hobe, "Der Rechtsstatus der Nichtregierungsorganisationen nach gegenwärtigem Völkerrecht", AVR 37 (1999), 152 et seq.; some important international conventions, including - to mention the example of an MEA - CITES, would not have been concluded without the assistance of NGOs, as it is pointed out by G. Pleuger/T. Fitschen, "GGiving greater opportunities to civil society to contribute to the goals and programmes of the United Nations“ - Die Vereinten Nationen und die Rolle der Nichtregierungsorganisationen", in: J. A. Frowein et al. (eds), Verhandeln für den Frieden. Negotiating for Peace, Liber Amicorum Tono Eitel, 2003, 193 et seq. (196). Cf. especially as to the development of the role of NGOs in international environmental law F. Yamin, "NGOs and International Environmental Law: A Critical Evaluation of their Roles and Responsibilities", RECIEL 10 (2001), 149 et seq.; P. Bombay, "The Role of NGOs in Shaping Community Positions in International Environmental Fora", RECIEL 10 (2001), 163 et seq.; S. Riedinger Die Rolle nichtstaatlicher Organisationen bei der Entwicklung und Durchsetzung internationalen Umweltrechts, 2001, 50 et seq.; D. Grimeaud, "Le droit international et la participation des organisations non gouvernementales à l'élaboration du droit de l'environnement: Une participation en voie de formalisation?", in: M. Pâques/M. Faure (eds), La protection de l'environnement au cour du système juridique international et du droit interne, 2003, 87 et seq. (137 et seq.); V. Röben, "Institutions of International Environmental Law", in: F. L. Morrison/R. Wolfrum (eds), International, Regional and National Environmental Law, 2000, 71 et seq. (107 et seq.).

2 Cf., for instance, Pleuger/Fitschen, see note 1, 197. 
particularly implicated in fields such as international environmental law and politics ${ }^{3}$ where "public interests" - to be seen as opposed to primarily "individual interests" - are discussed.

Nevertheless, the role of NGOs raises a certain number of fundamental questions which range from the integration of these "special actors" in the context of international law to the (democratic) legitimacy of NGOs, general questions which are especially important in the context of international environmental law where NGOs have a particular role.

Pursuant to the focus of this volume, the following contribution will concentrate on the role of NGOs in the process of assuring compliance with MEAs, so that the question of elaborating international law or other functions of $\mathrm{NGOs}^{4}$ shall not be discussed. It seems evident that the present role of NGOs in the compliance of international environmental law is already considerable; but in respect of the still remaining deficit as to the compliance with international environmental law obligations, further steps towards a stronger involvement of NGOs in the enforcement process have to be discussed. Thus, we will not only present some aspects of the current situation, but also try to develop some prospects with regard to the future, in consideration of the conditions for a useful and "legitimate" further involvement of NGOs in the enforcement of multilateral environmental agreements (III.). The basis for these reflections is a very short presentation of the legal basis in international law for the role of NGOs (II.). The contribution will finish with some conclusions (IV.).

\section{NGOs in international (environmental) law}

This is not the place to (re)define NGOs ${ }^{5}$. So the aim of the following observations is limited to clarifying the notion of NGOs as it is understood in this paper. As a point of departure, one has to admit that - even if a large number of international legal instruments refer to $\mathrm{NGOs}^{6}-$ a generally recognized definition of the term NGO does not exist ${ }^{7}$. Furthermore, the various organisations which are generally considered to be NGOs represent a very large variety and are very different ${ }^{8}$. Since the purpose of the following paper is to analyse the existent role of

3 Another example is the protection of human rights: Even if human rights are individual rights, their defence by the persons concerned is often very difficult and sometimes impossible.

$4 \quad \mathrm{Cf}$. as to the different functions of NGOs in the framework of international environmental law $\mathrm{S}$. Oberthür/M. Buck/S. Müller/S. Pfahl/R. G. Tarasofsky/J. Werksman/A. Palmer, Participation of NonGovernmental Organisations in International Environmental Co-operation: Legal Basis and Practical Experience, 2002, 40 et seq.

5 Cf. as to this issue from the pertinent literature, e.g., Pleuger/Fitschen, see note 1, 198 et seq.; H. H.-K. Rechenberg, "Non-Governmental Organizations", in: R. Bernhardt (ed.): Encyclopedia of Public International Law, Vol. III, 1997, 612 et seq.; Yamin, see note 1, 149 et seq.

6 Cf. e.g. article 71 UN-Charta, chapter 27 of Agenda 21, article 7 para. 6 UNFCC.

7 Cf. only Riedinger, see note 1,30 .

8 It is sufficient to consult - as far as this issue is concerned - the Yearbook of International Organizations 1999/2000, vol. 1B, 2356, where totally between 5825 and 43958 NGOs are counted pursuant to different criteria. The Yearbook is edited by the Union of International Associations. Cf. especially as to the domain of international environmental law the overview in P. Sands, Principles of International Environmental Law, $2^{\text {nd }}$ ed., 2003, 112 et seq.; P. Birnie/A. Boyle, International Law \& The Environment, $2^{\text {nd }}$ ed., 2002, 66 et seq. 
NGOs in the compliance of MEAs and to explore the perspectives in this respect, it seems useful to understand the notion of NGO in a rather wide sense; however, the context of the involvement of NGOs in the compliance of International Environmental Law always has to be bared in mind. This pleads in favour of considering the different definitions contained in environmental treaties ${ }^{9}$. Against this background, the following criteria ${ }^{10}$ shall define a NGO as it is understood in this paper ${ }^{11}$ :

- Independence from States and governments ${ }^{12}$ : Firstly, NGOs have to be distinguished from organisations established by inter-governmental agreements. Thus, NGOs are established in another way. Furthermore, it has to be guaranteed that they can express their views independently. This does not exclude membership of governments or funding by governments, but it has to be guaranteed that the organisation can express its views independently ${ }^{13}$. Members of NGOs can thus be individuals, groups of individuals and governments (the latter under the aforesaid condition).

- Objective: The organisation in question has to pursue a certain aim which is recognisable, e.g. environmental protection. This aim will in general also be reflected in the organisation's specific competences.

- Permanent organisation: The organisation must have a certain stability inasmuch as the factor time is concerned. Although one should not be too exigent in this regard, organisations set up spontaneously in order to pursue a very isolated political or other aim should be excluded. Therefore, a NGO has to orient its activities towards a longer, in principle undetermined perspective. This aspect also implies an evidence of current activities and a minimum of organisation/administration of the NGO's activity. However, it does not seem necessary for NGOs to have a certain organisational structure $^{14}$.

- Non-profit organisation: For the purpose of the present paper, it seems to be useful to exclude transnational enterprises/companies which exclusively or at least primarily pursue objectives of a commercial character. Indeed, it does not seem that such organisations are predestinated to ensure compliance of international environmental law in an independent way, given the fact that they in the first place generally pursue their economic interests ${ }^{15}$.

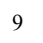

Cf. the summary of different definitions in international environmental treaties or in international organisations in Oberthür et al., see note 4, 22 et seq.

Cf. also the largely overlapping definition developped by Riedinger, see note 1, 29 et seq.; Oberthür et al., see note 4,21 et seq.

Cf., as the discussion among scholars and the practice of international organisations and (other) legal documents is concerned, the overview in Oberthür et al., see note 4, 28 et seq.; Riedinger, see note 1, 29 et seq.

This criterion is certainly the one which is in principle generally admitted. Cf. e.g. Rechenberg, see note 5,612 et seq.

Thus, also "hybrid organisations", especially such as the IUCN, are NGOs in this sense.

Cf. as to this issue Oberthür et al., see note 4, 22.

This does not exclude that these organisations may play a role in the development of international environmental law, cf. as to this purpose Oberthür et al., see note 4, 31, $54 \mathrm{ff}$. 
It does not seem - at this stage - to be useful to add further criteria, as e.g. a "democratic" organisation, activities at an international level or the absence of certain "lobbying activities". This would exclude some organisations from the scope of this paper even if they play or could play a certain role for the compliance with and enforcement of MEAs. However, it will be examined whether these differences can play a role while answering the question in which way and to which extent NGOs should participate in the compliance of MEAs. Therefore, and with regard to the wide range of different NGOs, it seems useful to present a very approximate classification of different types of NGOs. They can be distinguished according to different criteria ${ }^{16}$ :

- $\quad$ Aims and types of activities: The objectives of the NGOs and their types of activities can differ very much, even if one limits the focus to environmental organisations. Thus, the aim and activities can e.g. be to develop research activities or political activities ("pressure groups"), merely to contribute to the development of (international) environmental law and its compliance or to act outside the "normal" political and other procedures (by organising actions of protest).

Another criterion in this context can be the thematic range of activities (narrow or large).

- $\quad$ Type of membership: Members of NGOs can be of different origin. Thus, they can e.g. in their majority come from industrial or developing countries, members can exclusively be private persons or also governments or members can exclusively be groups of individuals or associations.

- Administrative and governance structure: NGOs can be organised in very different ways, and the differences can refer to various parameters. Thus, very strong participation of members can be foreseen or not, decisions can be taken either in a highly centralised or in a decentralised way and the administrative structure can vary considerably.

- $\quad$ Scope of activities: NGOs can be active at a regional, national or international level ${ }^{17}$.

- Finally, NGOs can be distinguished with regard to the manner of funding (mainly membership contributions, other funding such as donations, grants or government funds).

\section{NGOs and mechanisms of compliance with and enforcement of MEAs}

The role of NGOs in the compliance with MEAs raises - before it can be treated itself - the question as to which mechanisms can be considered to be compliance mechanisms (including

16 Cf. as to this issue Oberthür et al., see note 4, 32 et seq.; Riedinger, see note 1, 40 et seq., with further references.

17 Cf. to the role of ,grassroots”-NGOs and national NGOs M. Keck/K. Sikkink, Activists Beyond Borders. Advocacy Networks in International Politics, 1998, 140 et seq. 
enforcement mechanisms). This question is generally treated in another contribution ${ }^{18}$; for our purpose and pursuant to the focus of this volume, we can resume that under compliance (and enforcement) mechanisms all instruments are understood which apply after the coming into force of MEAs, and which tend to assure, to improve or to control the "right" application of MEAs by the Treaty Parties, including mechanisms of judicial or quasi-judicial control. If one tries to categorise these instruments, it seems possible to distinguish between three main types of compliance (and enforcement) mechanisms ${ }^{19}$ :

- mechanisms which tend towards "partnership solutions", i.e. which are of nonconfrontational character, such as reporting obligations, inspections, monitoring, assistance, but also compliance control (even if here the delimitation with confrontational measures may be difficult). The characteristics of these measures are that they in principle imply the cooperation and accord of the concerned Treaty Party;

- mechanisms which have a confrontational character such as (quasi-) judicial control or State responsibility. In this category, one finds measures which in principle compel Treaty Parties to behave in a certain way or to do something, even without their consent and cooperation;

- finally, there are mechanisms which cannot clearly be ranged in one of these categories because they do not really oblige States to conform to Treaty obligations or to take measures compensating the non-compliance of Treaty obligations; furthermore, they do not even specially refer to a certain MEA. However, they seem to be of crucial importance for compliance with MEAs because they refer to some general conditions necessary to assure compliance with MEAs. Here, one can in particular cite the obligations of States to concede information rights or to accord standing in internal judicial review procedures. But also other elements - which, however, cannot be dealt with in this paper - are relevant, particularly aspects of good governance and protection of human rights ${ }^{20}$.

This very short overview of the different sorts of compliance and enforcement mechanisms also makes clear that the role of NGOs for compliance control and enforcement of MEAs depends to a great extent on the general approach which is chosen in relation to compliance mechanisms, in other words on the mechanisms which are provided in the relevant MEAs in general. Thus, after a short recapitulation of the main types of involvement of NGOs in the enforcement of already existing MEAs (1.), we will also have to refer to some general aspects

18 Cf. the contribution of Jutta Brunnée in this volume.

19 Cf. as to the different mechanisms R. Wolfrum, "Means of ensuring compliance with and enforcement of International Environmental Law", $R d C$ 1998, 25 et seq. (56 et seq.); cf. also U. Beyerlin/T. Marauhn, Rechtsetzung und Rechtsdurchsetzung im Umweltvölkerrecht nach der Rio-Konferenz, 1997, 76 et seq.; Sands, see note 8, 171 et seq.; M. Bothe, "The Evaluation of Enforcement Mechanisms in International Environmenal Law", in: R. Wolfrum (ed.), Enforcing Environmental Standards: Economic Mechanisms as Viable Means?, 1996, 13 et seq.; A. Bree, Harmonization of the Dispute Settlement Mechanisms of the Multilateral Environmental Agreements and the World Trade Agreements, 2003, 81 et seq. In this respect cf. the Millennium Declaration, UN Doc. A/Res/55/22, no 3, 4. 
relative to the question which enforcement mechanisms should be provided in (future) MEAs (2.).

\section{Some selected aspects of the role of NGOs in the compliance and enforcement of MEAs}

As the reports on the enforcement mechanisms of selected MEAs in this volume show, there are already now different ways by which NGOs are implicated in the compliance with and enforcement of MEAs. Mainly, one can distinguish the following patterns ${ }^{21}$ :

\section{a) Non-confrontational mechanisms}

Non-confrontational mechanisms are mechanisms which demand cooperation and/or consent of the Treaty Parties. Their background very often consists in trying to prevent noncompliance, which is very often not a conscious decision, but rather reflects the incapacity of the concerned States to conform to some Treaty obligations ${ }^{22}$. The variety of nonconfrontational mechanisms is very large, but they can be divided in two principal groups: compliance assistance (aa) and compliance control (bb) ${ }^{23}$. In each field, NGOs can play an important role.

\section{aa) Compliance assistance}

The idea of compliance assistance is based on the fact that some States do not have the capacity to assure compliance with their Treaty obligations. Thus, various "assistance mechanisms" shall procure remedies to this situation by strengthening the relevant competences and means of Treaty Parties. They mainly concern capacity building in favour of the Treaty Parties, financial assistance, technical assistance and the creation of international

\footnotetext{
21 Cf. in detail with reference to concrete MEAs Riedinger, see note 1, 218 et seq.; see also Oberthür et al., see note 4, 45 et seq., 54 et seq. See also the overview in P. Bombay, The Role of Environmental NGOs in International Environmental Conferences and Agreements: some important features, EELR 10 (2001), 228 et seq. Cf. to the historical development Grimeaud, see note 1, 137 et seq. $\mathrm{Cf}$. as the different and very multiple reasons of non compliance are concerned, with further references, Riedinger, see note 1, 156 et seq., 241 et seq.; Bothe, see note 19, 17 et seq.; see also A. Chayes/A. Handler Chayes, The New Sovereignty, 1996, 8 et seq., who argue that in general deficits in application of MEAs are not intended but are the result of insufficient technical, administrative, financial and/or personal resources.

23 Cf. this distinction in Beyerlin/Marauhn, see note 19, 94 et seq., 121 et seq.; Riedinger, see note 1, 246 et seq.; see also Wolfrum, see note 19, 36 et seq., 110 et seq.
} 
institutions aiming at assuring compliance assistance ${ }^{24}$. NGOs are mainly involved in the following manner ${ }^{25}$ :

- $\quad$ NGOs participate in capacity building either by expressly being engaged to do so by international organisations or entities, especially UNEP and UNDP, or by acting independently and in engaging their own resources ${ }^{26}$.

- Insofar as financial support is concerned, NGOs primarily intervene independently of international organisations in two ways: Debt-for-Nature Swaps - where NGOs "buy" a part of the debts from a (developing) country which promises to undertake certain measures in the field of environmental protection $^{27}$ - and National Environmental Funds, which are local financial mechanisms which at an international level try to collect the funds in order to finance certain local measures ${ }^{28}$.

- Sometimes, international agreements refer to NGOs when the planning of projects is concerned.

In this respect, the Desertification Convention probably provides the most significant example for a farreaching integration of NGOs. This may be explained by the fact that the goal of stopping the desertification process cannot be realised without the cooperation of the local population. Thus, relevant projects have to be well defined and coordinated with the local population. Against this background, one can see the role of NGOs in the Convention: On the one hand, NGOs shall assure the link to the local population (cf. article 19 (1) (a), (3) UNCCD); on the other hand, the Convention considers NGOs as experts whose opinions shall be considered while developping strategies to combat desertification (cf. article 10 (2) (f) UNCCD). The integration of NGOs is obligatory for the Treaty Parties; however, the manner in which they are to be integrated is not formulated in a very precise way, so that Treaty Parties have a broad discretion.

- Finally, one has to mention institution building at an international level: Some international conventions attribute competences and/or tasks to NGOs which are in relation with the objective of the convention, especially as far as scientific tasks are concerned $^{29}$. Furthermore, NGOs may also contribute to the work of international institutions in an informal way ${ }^{30}$.

\section{bb) Compliance control}

24 Cf. in detail as to these different mechanisms e.g. Beyerlin/Marauhn, see note 19, 121 et seq.; Wolfrum, see note 19,117 et seq.

25 Cf. the overview by Riedinger, see note 1, 246 et seq.

26 Cf. as to this role of NGOs e.g. Riedinger, see note 1, 247 et seq.; see also Beyerlin/Marauhn, see note 19, 125 , both with references to several concrete examples.

27 Cf. to this instrument J. Heep, "From Private to Public: Giving Effect to the 'Debt' Component of Debtfor-Nature Swaps", GYIL 37 (1994), 422 et seq.; D. Kloss, Umweltschutz und Schuldentausch. Neue Wege der Umweltschutzfinanzierung am Beispiel lateinamerikanischer Tropenwälder, 1994, 90 et seq.; A. M. Pomar Borda, "International Experience with ,Debt-For-Nature Swaps", in: M. Bothe/P. H. Sand (eds), Environmental Policy. From Regulation to Economic Instruments, 2003, 417 et seq.

28 Cf. as to this instrument K. W. Danish, The Promise of National Environmental Funds in Developing Countries, International Environmental Affairs, 1995, 150 et seq.

29 See e.g. article 5 Antarctic Seals Convention, article 8 World Heritage Convention, article 8 Ramsar Convention.

30 Cf. as to this issue P. H. Sand, "Institution-Building to Assist Compliance with International Environmental Law: Perspectives", ZaöRV 56 (1996), 774 et seq. 
Compliance control refers to all mechanisms which serve in an institutionalised and formalised way to control the compliance of Treaty Parties with their Treaty obligations; in general, these mechanisms are guided by international bodies which are very often installed by the Treaty in question ${ }^{31}$. These mechanisms assure a certain transparency (by in an objective way establishing the facts which are relevant for the implementation of the Treaty provisions), and their results have a sort of disciplinary function for Treaty Parties. In addition, they shall contribute to a better compliance by the adoption of appropriate measures. Inasmuch as the involvement of NGOs in these mechanisms is concerned, the following aspects seem important ${ }^{32}$ :

- $\quad$ In the framework of implementation review mechanisms - which are contained in most recent treaties in the field of environmental law - reporting obligations for States, monitoring and/or inspections are provided $^{33}$. However, the detailed obligations of Treaty Parties vary considerably. These differences also refer to the extent of control: Thus, in most treaties only a control of implementation (in a "formal sense") is possible, whereas in others (especially the Montreal Protocol) a control of compliance in a larger sense is envisaged. Here, the role of NGOs is in general (but not always, the involvement of NGOs being sometimes expressely formulated in MEAs) an informal one in the sense that they contribute to informing the international bodies in an independent way about facts and problems.

Information given by NGOs can thus contribute to verifying and completing the reports of States $^{34}$ - which are often not very objective. Since NGOs participate in almost every Treaty conference, they can bring forward their point of view also in this context.

As far as monitoring - understood as a continuous collection of data concerning mainly environmental quality and the respective influence of human activities; it is thus not (as State reports) limited to activities directly linked to the fulfilment of Treaty obligations ${ }^{35}$ - is concerned, participation is normally restricted to large NGOs such as IUCN and some scientific institutes, mainly because of the high costs and the very specific competences required ${ }^{36}$. In contrast to the role of NGOs in reporting systems, their participation in monitoring systems is sometimes explicitely mentioned in Treaties, e.g.

31 Cf. e.g. the definition in Beyerlin/Marauhn, see note 19, 95. Cf. in detail as to the procedure of compliance control M. Ehrmann, Erfüllungskontrolle im Umweltvölkerrecht, 2000, especially 389 et seq., where he distinguishes different notions: compliance, implementation and effectiveness. Multilateral Environmental Agreements: From Tolerance to Recognition?", in: T. Treves et al. (eds), Civil Society, International Courts and Compliance Bodies, 2004, 205 et seq.

33 In detail as to these mechanisms in our context Riedinger, see note 1, 260 et seq.

34 Cf. Beyerlin/Marauhn, see note 19, 100; S. Oeter, "Inspection in International Law. Monitoring Compliance and the Problem of Implementation in International Law", NYIL 28 (1997), 101 et seq. (152).

35 So that the function of monitoring is not only compliance control but also to assure the availability of data in order to define adequate environmental policy. Cf. as to the monitoring and its functions K. Sachariew, "Promoting Compliance with International Environmental Legal Standards: Reflections on Monitoring and Reporting Mechanisms", YIEL, 2 (1991), 31 et seq.

$36 \mathrm{Cf}$. as to the involvements of NGOs in monitoring processes Riedinger, see note 1, 267-268. 
in the Washington Convention where IUCN and the network TRAFFIC, run by WWF and IUCN, play an important role.

Inspections - in the sense of compliance control in the concerned countries by visiting them in order to control certain activities or conditions ${ }^{37}$ - are still rather seldom in international environmental law, which is certainly linked to the relatively strong "intervention" in "internal" affairs implied by this means of compliance control ${ }^{38}$. This may also explain why very few MEAs accord a role to NGOs in the execution of those inspections; an exception is in this case (once again) the Washington Convention (CITES-Convention): Here, a decision of the Treaty Parties ${ }^{39}$ has entrusted TRAFFIC (in cooperation with the CITES Secretariat) to untertake certain inspections within the territory of Treaty Parties.

- In the framework of ad hoc Non-Compliance Procedures - which primarily tend to overcome the lack of compliance and which are initiated by a certain event and are not (as the implementation review procedures) applied more or less systematically ${ }^{40}$ NGOs (where this system is provided, as particularly in the Montreal Protocol, the Climate Change Convention or the Desertification Convention) are in general not entitled to trigger the procedure, contrary to Treaty Parties, the Secretariat or the concerned State. It is considered to be sufficient that NGOs can request the opening of such a procedure vis-à-vis Treaty Parties or the Secretariat ${ }^{41}$; however, a formalised procedure in order to treat the observations of NGOs is not foreseen, and in the framework of the Montreal Protocol the Secretariat is not even authorised to transmit other than the States' information to the Implementation Committee (in charge of undertaking the ad hoc Non-Compliance Procedure). However, very few other MEAs provide for a larger participation of NGOs, which are sometimes even generally admitted as observers, with the right to participate in the Compliance Committees, even if their rights in this framework differ. One especially has to note the Aarhus Convention and the Alpine Convention; in the framework of these Conventions, NGOs also have a limited right to trigger the Non-Compliance Procedure ${ }^{42}$.

These Non-Compliance Procedures enjoy a growing appreciation because they allow a better accommodation of the lack of reciprocity of obligations created by most MEAs. Furthermore, they in general provide for relatively flexible responses which can reach from appropriate financial and technical assistance, issuing cautions and suspensions of the Treaty operation to specific rights and privileges under the MEA. These suspensions may also effect rights considering production, consumption, trade, transfer

Cf. D. König, Durchsetzung internationaler Bestands- und Umweltschutzvorschriften auf Hoher See im Interesse der Staatengemeinschaft, 1990, 38.

Cf. for an overview over the existing inspection systems in international environmental law Oeter, see note 34, 150 et seq.; see also Wolfrum, see note 19, 43 et seq.; as to the ruling concerning the High Sea König, see note 37,37 et seq.

CITES, Decision of the Conference of the Parties, 10th Meeting (9-20 june 1997), Decision 10.2.

Cf. as to this instrument M. Koskeniemi, "Breach of Treaty or Non-Compliance? Reflections on the Enforcement of the Montreal Protocol”, YIEL, 3 (1992), 123 et seq. (128 et seq.).

Cf. Riedinger, see note 1, 271-272.

Cf. as regards the details of participation of NGOs in the Compliance Mechanisms of these Conventions Pitea, see note 32, 208 et seq., 212 et seq. 
of technology, financial mechanisms and institutional arrangements. In this respect, they can approach confrontational mechanisms.

As far as confrontational mechanisms - which are mechanisms implying a certain pressure are concerned, NGOs essentially play a role in judicial review or in procedures approaching judicial review (by instauring a procedure which tends to approximate the compulsory ascertainment of States obligations). They do not play any important role in State responsibility or in retorsion or countermeasures, which are, independently of the role of NGOs, not very important and suitable in international environmental law ${ }^{43}$.

As far as judicial review or quasi-judicial proceedings are concerned, it has to be mentioned that older MEAs do not provide for dispute settlements, whereas more recent MEAs generally contain dispute settlement clauses (e.g. article 20 Basel Convention, article 11 Vienna Convention, article 14 UNFCC). The typical clause stipulates that disputes - after negotiation or mediation - may be brought before the ICJ or an arbitration body under the condition that Parties have accepted the compulsory obligation to submit disputes to these bodies.

One can point out the following aspects regarding the role of $\mathrm{NGOs}^{44}$ :

- $\quad$ Before the ICJ, the role of NGOs is limited to indirect access ${ }^{45}$, even if article 34 (2) and 66 (2) of the statute of the ICJ could at least be interpreted in the sense that the Court may admit observations of $\mathrm{NGOs}^{46}$.

- $\quad$ Before the International Tribunal for the Law of the Sea, not only States or international actors but also certain private organisations can have standing; however, only organisations which participate directly in research or exploitation of the seabed are included in the relevant articles of the United Nations Convention on the Law of the Sea (UNCLOS) and the Statute of the International Tribunal for the Law of the Sea (arts 87, 153 (2) (b) SRÜ, article 37 of the Statue); thus, "external" organisations without any interests are excluded. The possibility of the Parties to conclude an agreement which provides that also other organisations can have access to the International Tribunal for the Law of the Sea remains unaffected ${ }^{47}$.

43 Cf. Beyerlin/Marauhn, see note 19, 77 et seq.

44 Cf. the overview to this issue in U. Beyerlin, "The Role of NGOs in International Environmental Litigation", ZaöRV 61 (2001), 357 et seq. Special mechanisms in supranational organisations, especially the EU, are not treated here, because they are not typical for the actual state of international law.

45 As Yamin, see note 1, 160, points out, NGOs managed to take part indirectly in the proceedings which led to the advisory opinion from the ICJ on the legality of nuclear weapons, inter alia by contributing - on behalf of the World Health Organization (WHO) - to the written pleadings and oral arguments before the Court.

46 Cf. as to this issue D. Shelton, "The Participation of Nongovernmental Organizations in International Judicial Proceedings", AJIL 88 (1994), 611 et seq.; see also R. Y. Jennings, "The International Court of Justice After Fifty Years", AJIL 89 (1995), 493 et seq. (504).

47 Cf. to this issue e.g. T. A. Mensah, "Dispute Settlement Regime of the United Nations Convention on the Law of the Sea", in: Max Planck Yearbook of United Nations Law, vol. 2 (1998), 307 et seq. (321); A. 
- $\quad$ The Appellate Body of the $\mathrm{WTO}^{48}$ has admitted - by applying article 13 (1) DSU amicus curiae briefs ${ }^{49}$ which contain observations of interested indivuals and mainly organisations, especially in the Shrimps-Turtle-Case ${ }^{50}$.

- In principle, NGOs can be Parties of treaties which install arbitration tribunals for a precise given problem. An example in the past is the Rainbow Warrior affair: Here, an arbitral convention was concluded between Greenpeace and France ${ }^{51}$. In practice, States revert very seldomly to this possibility, and States show considerable reluctance to become involved in international quasi-judicial proceedings.

c) Others: à propos some additional instruments

Apart from the mentioned "direct means" of participation of NGOs in compliance mechanisms, one has to point out the importance of some additional or flanking measures. They have to be seen in the context that NGOs can only act efficiently if a certain general framework is guaranteed which is necessary for their work. The following points are of particular importance:

- $\quad$ Freedom of activity: NGOs must benefit from a certain guarantee that their activities are not obstrued by the State. This aspect refers to the necessity of some fundamental guarantees, especially freedom of association and freedom of expression, so that there is a link to elements of "good governance". However, this element is not specific in the context of compliance of MEAs, but rather of general importance.

- $\quad$ Freedom of information: Obligations of States to render available certain environmental information and to guarantee the right of access of NGOs (but also of individuals) is an important element for NGOs in order to be active. In this respect, development in international law is in motion. As a very important element one has to mention the Aarhus Convention, which is, however, limited to European countries. It would be important to also develop the approach of the Aarhus-Convention at a more universal level.

- Access to justice: Also in the Aarhus-Convention, one can find some guarantees for NGOs (and individuals) providing access to justice in certain cases. This possibility is a necessary condition for NGOs in order for their namely information rights to virtually

Boyle, "Dispute Settlement and the Law of the Sea Convention: Problems of Fragmentation and Jurisdiction", ICLQ 46 (1997), 37 et seq. (53).

$48 \mathrm{Cf}$. to the judicial protection in the framework of the WTO W. Weiß, in: Weiß/Herrmann, Welthandeslrecht, 2003, $\S 10$, with further references.

49 Cf. in general the overview of the possibilities of NGOs to participate in litigations as amici curiae in Beyerlin, see note 44,363 et seq.

50 Cf. S. Ohlhoff, „Beteiligung von Verbänden in WTO-Streitbeilegungsverfahren. Das Shrimps-TurtleVerfahren als Wendepunkt?", EuZW 10 (1999), 139 et seq.

51 Cf. as to this issue A. Boyle, "Proliferation of International Jurisdiction and its Implications for the Court", in: D.W. Bowett et al. (eds), The International Court of Justice: Process, Practice and Procedure, 1997, 124 et seq. (125). 
be realised. Also in this respect, further guarantees beyond the European Countries are desirable.

If one tries to resume the present role of NGOs in the enforcement of international environmental law in general and MEAs in particular, the following aspects can be highlighted:

- In international judicial review procedures NGOs play a very marginal role; without the explicit consent of the implicated States they do not have standing in (quasi-) judicial procedures. The - in some points - more extensive possibilities in the framework of the Convention on the Law of the Sea are an exception and do not find any correspondence in other MEAs.

Nevertheless, NGOs can have some influence in international judicial review procedures by the sometimes granted possibility to present observations at the courts or arbitration tribunals as amici curiae. Moreover, they can inform States or (sometimes) other actors who have standing and try to influence them, so that they use their possibilities of judicial control. However, in international (environmental) law in general the possibility of judicial control without the consent of Treaty Parties is very rare. Insofar, strengthening the role of NGOs in this field would also imply some modifications as regards the "classical" possibilities of judicial control of obligations arising from international treaties.

- $\quad$ NGOs play an important role in compliance assistance. Very often this role is exerciced independently of a legal basis. It seems that the (potential) role of NGOs in this field is a very positive one since they are more flexible than governments, they also have a certain tendency to consider long-term aspects and they are often rather close to the reality $^{52}$.

- In compliance control, it is in the first place the independent information given by NGOs which is of crucial importance. However, since in general there is a lack of articles which deal with the formal status of information given by NGOs, a formalised discussion and consideration of their positions is not guaranteed and often blocked by governments $^{53}$, even if the participation at conferences held by Treaty Parties (which is not systematically guaranteed) of NGOs in any case assures a certain transparency ${ }^{54}$.

\footnotetext{
52 Cf. the positive evaluation in Riedinger, see note 1, 257-258.

53 Cf. T. Marauhn, "Towards a Procedural Law of Compliance Control in International Environmental Relations", ZaöRV 56 (1996), 696 et seq. (710). See also J. Cameron, "Compliance, Citizens and NGOs", in: J. Cameron/J. Werksman/P. Roderick (eds), Improving Compliance with International Environmental Law, 1996, 29 et seq. (36 et seq.).

54 Cf. M. Bothe, Compliance Control Beyond Diplomacy - the Role of Non-Governmental Actors, Environmental Policy and Law, 1997, 293 et seq. (296).
} 
Moreover, States are in general not obliged to take a position vis-à-vis the observations of NGOs. As far as inspections are concerned, NGOs could play a more important role at least as independent observators, but here the difficulty is also that very few MEAs really include inspections as a part of compliance control. In the framework of NCP (ad hoc Non-Compliance Procedures), participation of NGOs seems to be insufficient since there is no guarantee that their positions are really taken into consideration by the Secretariat and the Implementation Committee (in charge of undertaking the ad hoc Non-Compliance Procedure $)^{55}$. Finally, one has to admit that, in as far as compliance control is concerned, mainly very large NGOs with a high expertise play an influential role.

From an overall point of view, one has to state that the less State "sovereignty" is concerned, the more important becomes the influence of NGOs. As a consequence, it is not surprising that in judicial control their role is almost negligeable, whilst being slightly stronger in compliance control and even considerable in compliance assistance. In general, one can also observe a certain increase of the involvement of NGOs. Furthermore, it also becomes clear as already mentioned in the context of specific mechanisms - that the role of NGOs in compliance with and enforcement of MEAs is strongly dependent on the general aspects of existing compliance mechanisms.

\section{2. $\quad$ Future prospects}

The short overview of the present role of NGOs in compliance mechanisms has shown the increasing role of NGOs. Thus, in this part, the question shall be raised in which direction the involvements of NGOs in the compliance (control) of MEAs can and should go. As a point of departure one has to ask whether and, where required, to what extent there can be fundamental concerns against the involvement of NGOs in the compliance of environmental law or at least against the strengthening of their role in this respect (a). The answer to this question will to some extent also provide the framework for the discussion of the prospects for the involvement of NGOs in compliance mechanisms (b).

\section{a) A propos the role of NGOs}

A development in the sense of strengthening and formalising the role of NGOs in the enforcement process of NGOs implies a certain change in the international system as far as its actors are concerned, since according to the traditional notion of public international law, non-

Cf. Bothe, see note 54, 293 et seq. (295). 
state actors are not considered to be international legal persons ${ }^{56}$. This change has already begun, as the mechanisms set out before clearly demonstrate. However, this raises the question whether NGOs should have such an increasing role and which extent their role should reach. In this context, different categories of concerns are put forth, pleading in principle against a strengthening of the role of NGOs in compliance and enforcement (and "legislation"; which is, however not discussed here). The most important are the following ${ }^{57}$ :

- Lacking representativeness and (democratic) legitimation ${ }^{58}$ : NGOs are not - in a democratic sense of the notion - representative for a population. Besides, their structures are not necessarily democratic, which is also the case as far as (some) large organisations are concerned.

- $\quad$ Furthermore, the control of NGOs is not guaranteed, "the civil society" can certainly not assume this function.

- $\quad$ Finally, one can contest the means employed by some NGOs, for instance, when their protest actions are not undertaken within the framework of legality. This aspect is also linked to the lacking possibilities of controlling NGOs.

The outlined reasons against a further development of the role of NGOs are in some way pertinent: So, it is true that NGOs do not represent "the" civil society, but only, and this even only sometimes, their members. This problem is accentuated in the case of small NGOs. The lacking "institutional" control of activities of a large number of NGOs cannot be denied.

However, one has to take into consideration that - at least in this paper - only compliance and enforcement are in question, not the formulation of obligations of States or even individuals as such. Furthermore, certain forms of participation are taken into consideration. Thus, at least in this context, the aspects sketched out above are not able to convince: Legitimacy, representativeness and institutionalised control can only be demanded for actors who definitively formulate legal obligations or/and who are entrusted with institutional sovereign competences, e.g. in the enforcement of regulations. As a result, as far as the participation of NGOs relates to the level of consulted organs who have the right to formulate observations which have to be taken into account and who do not have the competence to assume real sovereign tasks, their involvement in compliance and enforcement mechanisms cannot be denied by stressing the arguments presented above. This also means that the participation of NGOs should not reach so far as to invest them with a sort of legislative or coercive power. If one wants to extend the competences of NGOs in this sense, one has to take measures in order to assure a certain legitimacy and a certain control (by, e.g., an adapted accreditation system). Furthermore, it does not seem useful or even practicable - in order to refute some of the arguments presented above - to distinguish different categories of NGOs, e.g. according to

Cf. Sands, see note $8,195$.

Cf. the résumé of the discussion in Riedinger, see note 1, 279 et seq.

Cf. as to this criticism J. Martens, „Dabeisein ist noch nicht alles - Die NGOs in den Vereinten Nationen: Akteure, Kritiker, Nutznießer“, VN 41 (1993), 168 et seq. (170), K. Hüfner, „Non-Governmental Organisations (NGOs) im System der Vereinten Nationen“, Die Friedenswarte 71 (1996), 115 et seq. (119). 
the prevailing aim of an organisation or its preferred activity (and thus exclude, e. g., NGOs acting primarily by means of public protest): Firstly, this distinction would hardly be practicable since it will not be possible to define the exact criteria an NGO has to meet. Secondly, organisations are generally involved in a wide range of very different activities. Thirdly, the decisive criteria should be whether the NGO in question is really able to fulfil the given tasks, which accordingly seems the most appropriate starting-point when defining the requirements. The same arguments can be put forth as to other requirements, e.g. the internal structure of NGOs.

\begin{abstract}
Furthermore, the reasons brought in against a strengthening of NGOs have to be relativised: A certain control of NGOs is assured by their funding: They are largely dependent on private donations. If their activities - which are observed by the medias - do not any longer have the consent of a sufficient number of people, they cannot continue with their activities. Nevertheless, certain NGOs which are to a large extent funded by individuals have to be exempt from this consideration. It has also to be taken into account that activities of different NGOs (and/or pressure groups) are an essential part of the democratic process. In other words: Different interests have to be represented by structures (the NGOs) if one tends towards that they can really have an impact. Finally, one has to take into account that there is a public interest that competent special organisations especially pursue the objective of protecting the environment as effectively as possible, which is a common concern. In this view, the decisive factor should not be the representativeness of a NGO, but its competence. The legitimacy of the NGOs seen against this background is their engagement in favour of a common concern and their competence, in other words: "authenticity of aspiration in a pluralistic society is thus the touchstone of legitimacy"s9.
\end{abstract}

Thus, as a result one can conclude that there are no reasons of fundamental nature not to include NGOs in the compliance process of MEAs or not to strengthen their involvement. One principle limit, however, has to be respected: NGOs may not be conferred the competence to take sanctions against private persons or public institutions; in this case, elements of the rule of law in principle hinder this sort of competence. Furthermore, it seems necessary to define the involvements of NGOs and their competences in a transparent and detailed way in MEAs themselves or in the decisions of the conferences of the Contracting Parties. By such reglementations, it should also be possible to guarantee the competence of NGOs. This consideration leads to another point: It does not seem appropriate to involve any NGO; one rather has to define - via an accreditation system - the NGOs which fulfil specific conditions for participation. These conditions have to be defined in dependence on the role NGOs should play in the framework of the compliance mechanisms. We will come back to this aspect in the following part of the paper.

b) Towards a strengthening of NGOs in compliance mechanisms: Some future options

On the basis of the reflections undertaken until now, it seems that strengthening the role of NGOs in compliance procedures is possible and useful mainly by involving them in different ways in the procedure itself without conferring them the power to themselves state in a

59 S. Wiesner, "Legitimacy and accountability of NGOs: A Policy-Oriented Perspective", in: W. Heere (ed.), From Government to Governance, 2004 (to be published). 
exclusive way, so that they should not have coercive competencies. The main reasons in favour of the further involvement of NGOs in the compliance and enforcement process result from the overview and evaluation of their actual activities:

- certain "control" of State activities;

- integration of independent knowledge, so that it can be avoided that relevant information is not taken into account;

- integration of organisations which pursue (solely or at least mainly) a common interest, in particular environmental protection;

- $\quad$ amelioration of the effectivity of compliance and enforcement by the participation of (namely national or regional) NGOs;

- $\quad$ transparency of compliance and enforcement procedures.

While trying to formulate some prospects in this sense, we first take the further development of already existing mechanisms, which may also be the most realistic scenario, as a point of departure (aa). In a second step, however, we will also develop some further (rather longterm) perspectives also implicating a further development of the general pattern of compliance mechanisms and of the general role of NGOs (bb). The following proposals only take the possible fields of action of NGOs into consideration which could or should be provided in international legal instruments. We do thus not take the multiple and very important forms of "informal" action of NGOs into account, independently of a legal basis.

\section{aa) With regard to the development of the existing role of NGOs}

As a point of departure, one has to remember the potentially very positive role which NGOs play or could play in the different existing compliance mechanisms. Thus, the leading idea of the following theses is to develop the systematic and formalised integration of NGOs as far as this makes sense for the mechanisms concerned ${ }^{60}$. The proposals ties in with the already developed different patterns of compliance procedures.

As already mentioned before, every formalised participation of NGOs in compliance mechanisms has to try to guarantee that NGOs can also fulfil the role they are intended to play. This means that the criteria which NGOs have to fulfil in order to participate in a formlised way have to be defined, and that a sort of accreditation system which can control the fulfilment of these conditions has to be installed. Furthermore, there must be a sort of continued control in the sense that an accreditation can also be withdrawn if a NGO does no longer meet the participation conditions. Finally, the accreditation has also to be seen against the background that one has - in order to guarantee the functioning of non-compliance mechanisms in practical and financial aspects - to somehow limit the formally implicated NGOs. In the framework of this paper it is not possible to develop these criteria exhaustively;

60 Cf. along these lines e.g. Pitea, see note 32,215 et seq. 
nevertheless, the following points can be stressed which, according to the functions just mentioned, NGOs should or could fulfil in the framework of compliance mechanisms ${ }^{61}$ :

- $\quad$ expertise of the NGO;

- $\quad$ predominance of environmental objectives in the work of the NGOs;

- $\quad$ certain transparency of financial and administrative organisation of the NGO;

- $\quad$ respect for the procedural rules laid down in the MEA.

The point of departure for the following remarks is that the outlined role of NGOs shall explicitely be formulated in MEAs or in decisions of the conference of Contracting Parties. The question whether it is useful to have a sort of general resolution or convention defining the different mechanisms of compliance and the role for NGOs in it, shall be treated below ${ }^{62}$.

(1) Non-confrontational mechanism: compliance assistance

In compliance assistance, NGOs should play a formalised role in capacity building, in institution building as well as in the definition and implementation of local projects. As far as financial support by NGOs is concerned, it does in general not seem useful to embody elements concerning these aspects in international treaties. In reference to some existing involvements of NGOs at these levels, one can formulate three theses:

1.1 MEAs or decisions of the conferences of Contracting Parties shall contain an obligation to have recourse to NGOs in the process of capacity building. In detail, it seems useful to formulate a general obligation (shall have recourse to NGOs) which has to be specified by the conferences of Contracting Parties, the Secretariat or the involved international bodies such as UNEP or UNDP. These precisions should mainly contain a formalised procedure of participation of NGOs during the elaboration of the different means of capacity building and define the role of (which) NGOs in the phase of implementation of the relevant actions.

This participation of NGOs should not exclude autonomous activities of NGOs in the field of capacity building.

1.2 As far as institution building at an international level is concerned, competent NGOs shall be involved in the field of the MEA. The MEA or decisions of the conferences of Contracting Parties shall specify the details.

${ }_{61}$ Since in different national legislations NGOs are integrated in the implementation of environmental policies and in compliance control, and since this function is parallel to the function of NGOs discussed here at an international level, one can also have a look at these national legal frameworks in order to develop the specific criteria and procedures for the accreditation of NGOs at an international level. However, the specific situation at the international level has to duly be taken into account. See cc). 
1.3 If MEAs contain the possibility or obligation to realise national, regional or local projects, they should contain an obligation for the bodies entrusted to realise these projects in coordination with NGOs who are active in the relevant field. The MEA (or decisions of the conferences of Contracting Parties) shall precise in which way NGOs are to be involved; it should be in a formalised way.

\section{(2) Non-confrontational mechanism: compliance control}

As far as compliance control is concerned, the role of NGOs depends - as in other fields of compliance mechanisms - on the procedures provided in MEAs: NGOs can only participate to the extent that a certain procedure is introduced in a MEA. Thus, the following suggestions also include some cautious suggestions regarding the further development of compliance control procedures.

2.1 State reports shall be systematically published, and NGOs shall have the possibility to formulate observations in a formalised procedure. The international bodies entrusted with the control of these reports shall have the obligation to consider these observations as well as those of States. Transparency will thus be improved and the supplementary value of NGOs observations will be used better.

2.2 With regard to monitoring, it seems that no general answer to the involvement of NGOs is possible, since the role of NGOs in monitoring depends on different factors, namely the monitoring mechanisms and the existence of competent and (also financially) strong NGOs. To the extent to which the basic conditions for a possible and useful involvement of certain NGOs are fulfilled, they shall participate in monitoring systems.

2.3 The strengthening of the role of NGOs in inspections (also) depends very largely on the question whether and to which extent inspections should be - in a more general way introduced in MEAs. In our opinion, here one can hardly develop a sort of general principle, e.g. in the sense that in every MEA and in respect of every MEA obligation inspections should (also) be introduced in the compliance system. Such a vision does not seem realistic at all, with regard to the implications for Treaty Parties. In this context, it has to be beared in mind that not even in the European Union general inspections are provided; here, other mechanisms of compliance control involving (in the opinion of Member States) less ingerence in home affairs prevail. Thus, it is hardly imaginable that at an international level competences for international bodies could and even should go further. Moreover, inspections do not seem an appropriate measure for compliance control of all possible obligations arising from MEAs. On the contrary, one can affirm that they are only useful and only make sense for 
those obligations which include rather precise obligations for Treaty Parties. It is useful to note that in current international law inspections are provided mainly in the field of disarmament where one has rather precise data as to what must be reduced and when.

Thus, MEAs (or decisions of the conference of Contracting Parties) shall introduce inspections only for such obligations which are sufficiently precise and in respect of which inspections can make sense. To the extent to which inspections are introduced, it seems very useful to permit NGOs to take part in the inspection delegation and/or to present observations as the inspection result/report is concerned. For other obligations arising from MEAs, a more formalised and strengthened reporting system (with the participation of NGOs outlined before) seems to be more adequate.

\subsection{As far as ad hoc Non-Compliance Procedures are included in MEAs, the role of NGOs} shall be strengthened: In particular, it seems to be useful or even necessary to introduce a formalised procedure in which observations of NGOs are considered. This procedure shall include the publication of the NGOs' observations and the obligation of international bodies and Treaty Parties to take position on the content of these observations.

A recent example in this context is the Convention on the Protection of the Alps with its Protocols adopted in November 2002: NGOs are enabled to participate - under certain conditions of confidentiality - in the controlling mechanisms concerning implementation and enforcement of the Convention.

Furthermore, one can raise the question whether and to which extent NGOs shall be entitled to trigger the Non-Compliance Procedure. Such a competence is already realised in other domains of international law, namely human rights and international labour law ${ }^{63}$. Against such a role of NGOs one could bring in that these "models" can not be transposed fully to the domain of international environmental law, because in general they presuppose individual rights. Furthermore, such a right could not be in conformity with the cooperative character of compliance control in international environmental law and would risk to be ineffective ${ }^{64}$. In our point of view, these arguments are not able to convince: Firstly, it is not clear why the possibility for NGOs to trigger the compliance procedure presupposes a subjective right. One can also take as a point of departure that the compliance procedure has to be considered as an objective procedure which can be triggered by different institutions, States or other bodies having this capacity. Whether or not such a competence should be assigned to NGOs seems to be a political rather than a conceptual question. As far as the cooperative character of NonCompliance Procedures is concerned, it is first of all to be stressed that they in some sense in fact also have a confrontational character since sometimes independent bodies or other States can trigger them and since the possibilities of reaction also cover measures approaching "sanctions". In favour of a direct participation of NGOs one can put forth that by this means, an independent actor could - in some sense as a trustee, having in mind the common interest

63 Cf. Ehrmann, see note 31, 458 et seq., with further references.

${ }^{64}$ Cf. along these lines Ehrmann, see note 31, 459-460. 
of environmental protection - trigger the Non-Compliance Procedure if for political reasons State actors (and sometimes even existing, rather independent Treaty bodies) renounce to do so.

As a result, better reasons plead for the capacity of NGOs to initiate the Non-Compliance Procedure; by this means, aspects of institutional control (which are, to a minor degree, already present in some MEAs, especially the Montreal Protocol) could be strengthened. However, this does not mean that NGOs should have the possibility to directly "attack" the concerned States; if one ties in with the existing models, one rather has to imagine that NGOs have a right to request the competent body (as the "Implementation Committee" in the Montreal Protocol) to start the procedure. Then, the procedure takes its "normal" course, meaning that the competent body can conclude at a violation of Treaty obligations or not, and has to define, in the framework of the MEA, the measures to be taken ${ }^{65}$. It does not seem that such a model would go too far in terms of the interference in "internal" affairs, since it is just the beginning of the procedure which is altered.

As an example of such opportunities for NGO participation one can mention the potential role attributed to NGOs (and individuals as well) under the North American Agreement on Environmental Cooperation (NAAEC), which is closely linked to the North American Free Trade Agreement (NAFTA) ${ }^{66}$. Under the NAAEC a specific organ (Commission for Environmental Cooperation) has been established in order to promote the Agreement's objectives, which comprise - among others - „to enhance compliance with, and enforcement of, environmental laws and regulations“, and to foster „transparency and public participation in the development of environmental laws, regulations and policies ${ }^{\text {“67 }}$. Among the various stipulations relating to public participation within the NAAEC, it is of special interest in the present context that the CEC's Secretariat has the competence to „consider a submission from any non-governmental organization or person asserting that a Party is failing to effectively enforce its environmental law ${ }^{668}$. As a possible consequence (if the Secretariat finds that such a submission meets certain criteria), the State Party concerned may be requested to give a response to the allegation of environmental regulations not being complied with ${ }^{69}$.

Furthermore, an accreditation system of NGOs could prevent that too many and incompetent NGOs can act in that way. For instance, one could imagine the Treaty Secretariat to have the competence to accredit a certain number of NGOs, on the basis of respective criteria laid down in the MEA itself or in a specific decision of the conference of the Parties. The criteria for the participation of NGOs which are accorded a consultative status with the UN Economic and Social Council (ECOSOC) may serve as an example: On the basis of art. 71 of the UNCharter, which enables the ECOSOC to make ,suitable arrangements for consultation with

65 This raises, however, the question whether the non-compliance procedures should be modified in the sense that the independence of the institutions involved should be strengthened. Because at the moment, the ascertainment of a violation is in general up to representatives of governments or at least to persons named by governments. Cf. below bb). As to the following cf. Wm. C. Muffet, "Environmental Cooperation in North America", in: F. L.Morrison/ R. Wolfrum (eds), International, Regional and National Environmental Law, 2000, 505 et seq. (528 et seq.). Article 1 (g)-(h) NAAEC; cf. ILM 32 (1993), 1480 et seq.

Article 14 para. 1 NAAEC.

Article 14 para. 2 NAAEC. 
non-governmental organisations which are concerned with matters within its competence“, rules for the admission of NGOs have already been established in $1946^{70}$.

However, one has to admit that at the moment it is very uncertain whether States will accept such a mechanism at all.

2.5 In general: NGOs shall be admitted - after an accreditation, as mentioned before - to the meetings of the Contracting Parties and have access to relevant documents, the right to intervene in deliberations and the right to submit written observations. This should include access to steering committees entrusted with the discussion of State reports and different measures of compliance control. There should be a formalised procedure regarding the treatment of observations by NGOs.

This approach would strengthen the transparency of procedures and contribute to a more objective discussion where not merely State interests prevail.

The concerns as to the necessary confidentiality of such meetings, which by all means must be taken seriously, can be met by appropriate provisions in the rules of procedure (commitment to the confidentiality of at least certain documents, enabling of corresponding decisions or similar).

\section{(3) Confrontational mechanism}

If judicial control is foreseen in MEAs ${ }^{71}$, it seems to be useful - always within the idea of strengthening the existent approaches - to introduce a formalised possibility for NGOs to take a position on the issue (in the sense of amici curiae). Furthermore, it seems useful to open the possibility for NGOs to address to Treaty Parties and international bodies observations which could be useful for them for their decision to open the procedure of judicial control.

\section{(4) Evaluation}

The overview over the different possibilities in order to strengthen the position of NGOs in the framework of existing compliance mechanisms and in widening the already existing possibilities of action of NGOs has shown that there are indeed potentials which all have one point in common: The strengthening of the procedure by introducing formalised mechanisms for NGOs in order to put forward their point of view and by obliging Treaty Parties and international bodies to take these observations into account or to take a position, respectively. If the development goes in this direction, the participation of NGOs will improve the

\footnotetext{
70 Cf. ECOSOC Res. 3 (II); as to the details of the admission procedure set up within the ECOSOC see Pleuger/Fitschen, see note 1, 206 et seq.; Rechenberg, see note 5, 614 et seq.

71 As to the development cf. below b).
} 
transparency of compliance procedures and contribute to render other points of view available. These approaches fit very well into the present mechanisms and proceed with the developments which we have been able to observe for several years.

\section{bb) Some long-term prospects}

In an attempt to go a step further, beyond the mere expansion of already existing mechanisms as it has just been outlined, the question may be put forward whether new forms of participation of NGOs should be considered for the future in order to render compliance procedures more effective (in other words: every further implication of NGOs in compliance mechanims shall be organised in a way that the procedures become more effective). In view of the current situation and the possible developments of existing mechanisms, which constitute the point of departure ${ }^{72}$, no fundamental modification of the role of NGOs seems necessary with regard to compliance assistance; even now, on the basis of the existing procedures and their further development, NGOs have acquired an important status.

On the other hand, as far as the role of NGOs in (ad hoc) non-compliance control and judicial review is concerned, their position is rather weak at present. Moreover, the potential for further development of existing mechanisms is rather limited with regard to the key issue of a lack of participation of NGOs. It must also be admitted that the limited role of NGOs in this context is narrowly linked with the actually restricted function of these mechanisms in general, which has to be seen - as mentioned before - against the background of the loss of "sovereignty" linked with these mechanisms at least in the point of view of a lot of States.

As to this last aspect, the following remarks should, however, also be taken into consideration: If one admits the "common concern" of environmental protection and the necessity of common action (the conclusion of a MEA seems to show this), the installation of effective compliance and enforcement procedures is in fact only a compulsory consequence. In other words, it does not seem to make sense to conclude MEAs and to on the one hand consider the obligations in there as important for all, but to on the other hand refuse effective procedures. However, every enforcement of compliance procedures, especially by further involving NGOs, can be considered as contributing to the constitutionalization ${ }^{73}$ of international (environmental) law $^{74}$. This development can be observed in general, and it has to be stressed that it does not mean an abandonment of "sovereignty" in the sense of a loss of statehood; it just implies a further-reaching application of international law and a consent in some procedures which limit the exercice of sovereign rights in the respective fields. This

Cf. III.1.a)aa); III.2.b)aa).

As regards the concept of the „constitutionalization“ of international law cf., among many other authors, J. A. Frowein, „Konstitutionalisierung des Völkerrechts“, BDGVR 39 (2000), 427 et seq.

As to the role of international environmental law in the context of an ,international constitutionalization" cf., for instance, M. Scheyli, "Der Schutz des Klimas als Prüfstein völkerrechtlicher Konstitutionalisierung?", $A V R \quad 40$ (2002), 273 et seq. 
evolution process is also present in other fields of law, as the examples of the competences of the UN Security Council or the procedures foreseen in the ECHR may illustrate. One can also cite the example of the EU - however a supranational organisation - in which States concede sovereign powers to the EU level in a very profound way. Finally, one has to mention that better compliance control and judicial review concern every Treaty Party and every obligation without any distinction, so that not only obligations directly concerning environmental protection issues are covered, but also those (e.g.) concerning financial and other (compliance) assistance.

If one now tries to imagine the direction in which compliance procedures and the respective role of NGOs might develop, relating considerations may proceed from the fact that the actual mechanisms as they are structured now cannot, in general, assure a really independent compliance control. This is true for compliance control as well as for judicial review. Since the present instruments are very consensual (in the sense that States actually almost have to denounce themselves), it becomes clear that such a system must fail in a lot of situations where real problems of non-compliance arise. Moreover, the current system does not allow an independent and authoritative interpretation of the legal meaning of MEA obligations. This is highly regrettable, especially since provisions in these treaties are sometimes not very clear, so that the different actors very often do not just discuss issues of non-compliance but have divergent views as to the exact meaning of obligations.

Against this background, when it comes to thinking about more effective compliance mechanisms, the following points should be considered seriously:

- As far as the institutional structure is concerned, it seems useful - by developing the already existent approaches of autonomous institutional arrangements in MEAs ${ }^{75}-$ to introduce independent international bodies which - perhaps among other competences are charged with surveying the effective application of the MEA. Such an internationalisation would render the procedure more objective and the effective survey would not be dependent on the will of the Contracting Parties. Such bodies would act in a more independent way than the "traditional" secretaries or the "traditional" compliance committees, the latter ressembling in general to political organs since they are dependent on Treaty Parties ${ }^{76}$. The procedure and the rights of this survey body, the Contracting Parties and NGOs must be laid down in detail ${ }^{77}$.

NGOs should in this context have a right to present observations and to inform this body about relevant factors. Furthermore, it has to be kept in mind that NGOs should have the "formal possibility" to trigger a Non-Compliance Procedure ${ }^{78}$.

Cf. as to this issue R. R. Churchill/G. Ulfstein, "Autonomous Institutional Arrangements in Multilateral Environmental Agreements: A Little-Noticed Phenomenon in International Law”, AJIL 94 (2000), 623 et seq.

76 Very exceptionally, however, there may also be real independent persons in the compliance committee, as for instance in the Aarhus Convention.

77 Cf. in detail as to this issue Marauhn, see note 53, 722 et seq.

78 Cf. above, III.2.b)aa) 2.4 .
} 
- With regard to judicial control ${ }^{79}$, two mechanisms should be considered: Firstly, there should be the possibility for Treaty Parties and the just mentioned independent body to bring (by means of a procedure yet to be defined) questions of interpretation of Treaty obligations before another independent (judicial) body whose decisions are binding for Treaty Parties and Treaty Institutions. Furthermore, the mentioned independent body should have the possibility to challenge an independent (judicial) body in order to have an ascertainment that a Treaty Party does not conform with its Treaty obligations. This option should be linked with existing Non-Compliance Procedures. The background for this purpose is the idea that judicial control by independent institutions is surely not a sufficient means to assure compliance with MEAs, but in view of the still existing huge deficiency of compliance, it seems to be - also in view of the experiences at national level and in other fields - a necessary means to contribute to the amelioration of application of $\mathrm{MEAs}^{80}$. One can imagine that the Permanent Court of Arbitration plays a certain role in this context ${ }^{81}$.

As for the role of NGOs, they should in both procedures have the right to present observations which are to be taken into due consideration. In the latter case, one can furthermore imagine that they inform the independent body. Finally, standing for determined NGOs should be granted when MEAs confer rights to them.

Of course, general standing - under the condition of an accreditation procedure - is also imaginable. Good reasons plead in favour of such an access, in particular the addition of independent actors having the possibility to claim the non-respect of MEAs obligation by States ${ }^{82}$. Furthermore, reasons generally brought in for the introduction of standing of NGOs at national level are in principle also pertinent at an international level. However, one has to prevent contraproductive effects, especially the possibility of claims getting out of control. This could be reached by an appropriate accreditation procedure. Such means of NGOs taking part in judicial procedures also have to be coordinated with their role in non-compliance mechanisms.

However, one has to stress that this aspect of judicial control can only be one factor among others on the way to improving compliance; at least equally important is the

$79 \quad$ Here we will not discuss the issue of an international environmental court. Cf. as to his issue A. Rest, "Zur Notwendigkeit eines internationalen Umweltgerichtshofs", in: G. Hafner/G. Loibl/A. Rest/L. Sucharipa-Behrmann/K. Zemanek (eds), Liber amicorum Ignaz Seidl-Hohenveldern, 1998, 575 et seq.; M. R. Albus, Zur Notwendigkeit eines Internationalen Umweltgerichtshofs, 2000; see also Bree, see note 19,406 et seq.

80 In this direction namely also A. Rest, "Enhanced Implementation of International Environmental Treaties by Judiciary - Access to Justice in International Environmental Law for Individuals and NGOs: Efficacious Enforcement by the Permanent Court of Arbitration", MqJICEL 1 (2004), 1 et seq. (2-3, 9 et seq.). Cf. also Principle 26 of the Rio Declaration and point 39.10 of Agenda 21, where the importance of judicial settlement of disputes is emphasized.

81 As to this perspective Rest, see note 80, 19 et seq., who also resumes the PCA Optional Rules for Arbitration of Disputes Relating to Natural Resources and/or the Environment.

82 In favour of such a possibility e.g. Rest, see note 80, 9 et seq.; Bree, see note 19, 421-422; more sceptical in relation to non-compliance procedures Ehrmann, see note 31, 458 et seq. 
strengthening of cooperative procedures. Finally, it has to be admitted that at present States are not (yet?) ready to approve of such a solution.

- As far as substantive obligations for Treaty Parties are concerned, first of all one can imagine the introduction of formalised cooperation duties between Treaty Parties and independent bodies foreseen in the MEA. Furthermore, and this would be of particular importance for NGOs, it seems useful and even necessary to extend the validity of the Aarhus Convention universally, perhaps by adapting its regulations to some particular situations. But the principles stipulated in the Aarhus Convention - that States have to render available environmental information, give access to environmental information, guarantee the participation of the public in certain decision procedures and provide judicial review under certain conditions - seem to be necessary conditions and corollary to the role of NGOs in compliance procedures.

cc) With regard to the question of a cross-sectoral convention on compliance mechanisms and the respective role of NGOs

As far as the legal forms of involvement of NGOs in compliance procedures are concerned, they are until now always laid down in the MEA itself, or the conference of Contracting Parties takes the relevant decisions on this subject. We thus have a multitude of compliance regimes deriving from the various MEAs which differ to a great extent in terms of their structure and even of certain details (when parallel structures are recognisable). Furthermore, it often lies in the competence of States to exclude NGOs from participation in certain procedures. This raises the question whether it could be useful to develop a sort of general code for compliance mechanisms ${ }^{83}$. Such a code could also include a sort of "admission procedure" for NGOs, which should ensure their competence and that they really pursue the objective of environmental protection.

Against this perspective one can invoke that every MEA and even every obligation arising from international environmental law has its own characteristics which claim their own compliance procedures. A sort of general code could - under this perspective - not take the differences between MEAs and obligations of international environmental law into account. Another point is that the Treaty Parties of such a ,general convention“ would not necessarily be the same as the Parties of the different MEAs.

Nevertheless, the advantages of such a general formulation of different compliance mechanisms and the respective role of NGOs would be considerable: One could arrive at a sort of categorisation of different possible procedures and the principle conditions for their application. Thus, if this general part of compliance procedures contained different typical

83 Cf. for an example of such a cross cutting resolution ECOSOC Res. 1996/31, which has however been criticised. 
variations of procedures, an adaptation to the characteristics of each MEA would be possible. If the Treaty Parties of a certain MEA intend to choose an option that deviates from the procedures which are stipulated generally, they have to explain the reasons for doing so. As far as the question of Treaty Parties is concerned, it seems useful - at least in a first step - to refer to a (as far as possible) generally accepted resolution and to tie in with the content of such a resolution in the MEAs. At a later stage, a convention could be envisaged whose content (the relevant compliance procedures, that is) could also be included in every separate MEA, while - as mentioned before - adapting the respective procedures to the specific features of each MEA.

Such a convention on participation of NGOs in international environmental law making ${ }^{84}$ and enforcement should include - as far as compliance and enforcement procedures are concerned - the following points:

- the principle of access of NGOs to official documents (and their communication to NGOs);

- $\quad$ the different compliance mechanisms;

- the institutional structure of compliance mechanisms (probably with different possibilities); in this context, one has to consider if, as far as e.g. the independent body or the organ competent for judicial review is concerned, it would make sense to have a common institution for several MEAs;

- $\quad$ minimum standards for the participation of NGOs in compliance and enforcement by distinguishing the different levels already mentioned (compliance assistance, compliance control, judicial review), with special attention to the procedural aspects (formalised participation of NGOs);

- $\quad$ some variants which present further going rights of participation for NGOs and which present "typical" means of NGO involvement;

- $\quad$ accreditation conditions and procedure for NGOs.

The conclusion of such a convention would probably be a step towards the recognition of a partial international law subjectivity of $\mathrm{NGOs}^{85}$, since their right would be conferred in such a document ${ }^{86}$.

\section{Conclusions}

$84 \quad$ Probably, one should also integrate the role of NGOs in the process of law making in such a convention.

85 However, it seems too far-reaching to claim ,de considérer les personnes physiques et morales en tant que sujets du droit international au même titre que les nations". Cf. Grimeaud, see note 1, 136.

86 As to the question whether NGOs already have a partial international law subjectivity S. Hobe, "Der Rechtsstatus der Nichtregierungsorganisationen nach gegenwärtigem Völkerrecht”, ArchVR 37 (1999), 152 et seq. 
There can be little doubt that the role of NGOs in the international legal system will increase further ${ }^{87}$ with regard to international law-making as well as to implementing the given rules. This general prognosis also extends to the particular sphere of international environmental law. However, it still remains unclear by which concrete means and to what extent this development will unfold.

In this context it has to be stressed that a strengthening of the role of NGOs in the sense outlined in this paper does not mean to put them on the same level as States nor does it imply that any NGO should have every formalised right mentioned in the paper. The role of NGOs should rather be a clearly complementary one, and furthermore the mentioned accreditation system has to guarantee the operativeness of the system.

The present article is an attempt to draft, on the basis of an overview of existing opportunities for NGO participation, some future prospects for an effective involvement of NGOs in ensuring compliance with international environmental regulations. The respective considerations suggest the estimation that, while arguments frequently brought forward against more participation rights of NGOs (such as a certain loss of State sovereignty) do not convince, strengthening the role of NGOs in compliance mechanisms would result in many positive effects:

- Mainly generally speaking, enhancing the role of NGOs in the international system implies a further reinforcement of the „civil society", which is a widely acknowledged goal in international politics.

- As far as global governance is concerned, which implies strenghtening the role of "civil society", positive effects could be expected for transparency as regards the implementation of international law.

- $\quad$ Particularly in view of the concept of sustainable development, whose implementation demands an integration of endeavours at all levels of governance ${ }^{88}$, every means of improving the functioning of environmental regulation is highly welcome.

- A more effective use of the wealth of expert skills and knowledge which is concentrated in NGOs (especially in the large ones) is crucial with regard to the overarching goal of improving the enforcement of international environmental standards; this can be achieved by furthering the integration of NGOs in the institutional mechanisms already existing in the field of international environmental regimes ${ }^{89}$.

- $\quad$ The existence of effective dispute settlement mechanisms can be considered as an indispensable element in the process of constitutionalization of public international

\footnotetext{
87

Cf. R. Wolfrum, "International Environmental Law: Purposes, Principles and Means of Ensuring Compliance", in: F. L. Morrison/R. Wolfrum (eds), International, Regional and National Environmental Law, 2000, 3 et seq. (4).

88 Cf. on this aspect also Yamin, see note $1,161$.

89 Cf., as regards the role of (in particular environmental) NGOs in the WTO: R. Schmidt/W. Kahl, "Umweltschutz und Handel", in: H.-W. Rengeling (ed.), Handbuch zum europäischen und deutschen Umweltrecht (EUDUR), Vol. II/2, $2^{\text {nd }}$ ed., 2003, § 89 para. 158.
} 
$\mathrm{law}^{90}$. It seems clear that an international dispute settlement system which provides for the participation of members of civil society would furthermore augment its "constitutional significance", not least by enhancing the legitimacy of the decisions to be taken. Hence, involving NGOs in judicial or quasi-judicial control mechanisms also serves the purpose of contributing to the constitutionalization of the international legal order. D. Z. Cass, "The ,Constitutionalization" of International Law: Judicial Norm-Generation as the Engine of Constitutional Development in International Trade”, in: EJIL 12 (2001), 39 et seq.; E.-U. Petersmann, "Constitutionalism and International Adjudication: How to Constitutionalize the U.N. Dispute Settlement System?”, in: NYUJILP 1998-1999, 753 et seq. 